\title{
Carta del Presidente del Colegio Argentino de Cardioangiologías Intervencionistas (CACl)
}

\author{
Letter from the President of CACl
}

Revista Argentina de Cardioangiología Intervencionista 2016;7(4):242

Hemos finalizado el 2016 pudiendo concretar las metas propuestas al comenzar las gestiones de esta nueva comisión directiva. Con gran alegría quiero compartir con todos Uds. la puesta en funcionamiento del Vademécum CACI, el cual sabemos va a convertirse en una herramienta de ayuda permanente en nuestra diaria actividad profesional.

En la asamblea ordinaria de fin de año se ha aprobado la implementación del subsidio solidario por enfermedad CACI, el cual está destinado a colaborar con aquellos socios colegas que por motivos de enfermedad no puedan realizar la profesión por más de un mes, intentando con esto apoyar económicamente a quienes lo necesiten.

Somos los primeros en el país en la implementación de un sistema digital de medición personal de dosis de radiación, incorporando ya los primeros 200 dosímetros digitales y un convenio con un físico médico de reconocida experiencia en el área, para llevar a cabo la tarea de control de dosis y alertas en nuestros colegas. Dentro de todas las actividades científicas que realiza nuestro colegio quiero destacar nuestro Congreso anual 2016 el cual fue realizado este año en la ciudad de Mar del Plata con más de trescientos asistentes y que gracias al constante apoyo de la industria y de nuestros compañeros marplatenses fue realmente un éxito en todos los sentidos.

Como es habitual, hemos organizado nuestros simposios de Cardiología Intervencionista, dirigidos a cardiólogos clínicos e intervencionistas en los Congresos Nacionales de la Sociedad Argentina de Cardiología y de la Federación Argentina de Cardiología. Hemos tenido sesiones dentro de congresos internacionales como el TCT, PCR, C3 logrando la participación de más de 100 colegas argentinos en dichas reuniones científicas, lo cual creemos que constituye una ayuda al permanente perfeccionamiento científico de nuestra especialidad.

En los últimos días hemos concretado una nueva sesión argentina con la participación del CACI en el China Interventional Therapeutics (CIT).

No podemos dejar de mencionar a la Carrera de Cardioangiólogos Intervencionistas, al Programa de Actualización en Cardioangiología Intervencionista y a la Revista RACI como medios permanentes de formación y educación en nuestra especialidad.

Sin duda, todo esto se logra por el esfuerzo mancomunado de mucha gente, a quienes aliento para seguir trabajando por el crecimiento de nuestro colegio y de nuestra especialidad.

Les deseo a todos muy Felices Fiestas!

Dr. Alejandro Cherro

Presidente del Colegio Argentino de Cardioangiólogos Intervencionistas (CACI) 